\title{
Front Matter: Volume 11863
}

, "Front Matter: Volume 11863," Proc. SPIE 11863, Earth Resources and Environmental Remote Sensing/GIS Applications XII, 1186301 (6 October 2021); doi: $10.1117 / 12.2614831$

SPIE. Event: SPIE Remote Sensing, 2021, Online Only 


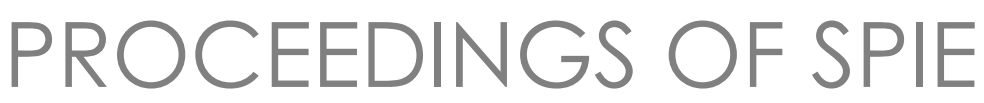

\title{
Earth Resources and Environmental Remote Sensing/GIS Applications XII
}

\author{
Karsten Schulz \\ Ulrich Michel \\ Konstantinos G. Nikolakopoulos \\ Editors \\ 13-17 September 2021 \\ Online Only, Spain \\ Sponsored by \\ SPIE \\ Cooperating Organisations \\ European Optical Society \\ EARSeL-European Association of Remote Sensing Laboratories (Germany) \\ ISPRS - International Society for Photogrammetry and Remote Sensing \\ CENSIS (United Kingdom) \\ SEDOPTICA \\ Supporting Organisation \\ INEUSTAR/INDUCIENCIA \\ Published by \\ SPIE
}

Volume 11863 
The papers in this volume were part of the technical conference cited on the cover and title page. Papers were selected and subject to review by the editors and conference program committee. Some conference presentations may not be available for publication. Additional papers and presentation recordings may be available online in the SPIE Digital Library at SPIEDigitalLibrary.org.

The papers reflect the work and thoughts of the authors and are published herein as submitted. The publisher is not responsible for the validity of the information or for any outcomes resulting from reliance thereon.

Please use the following format to cite material from these proceedings:

Author(s), "Title of Paper," in Earth Resources and Environmental Remote Sensing/GIS Applications XII, edited by Karsten Schulz, Ulrich Michel, Konstantinos G. Nikolakopoulos, Proc. of SPIE 11863, Sevendigit Article CID Number (DD/MM/YYYY); (DOI URL).

ISSN: 0277-786X

ISSN: 1996-756X (electronic)

ISBN: 9781510645707

ISBN: 9781510645714 (electronic)

Published by

SPIE

P.O. Box 10, Bellingham, Washington 98227-0010 USA

Telephone +1 3606763290 (Pacific Time)

SPIE.org

Copyright (C) 2021 Society of Photo-Optical Instrumentation Engineers (SPIE).

Copying of material in this book for internal or personal use, or for the internal or personal use of specific clients, beyond the fair use provisions granted by the U.S. Copyright Law is authorized by SPIE subject to payment of fees. To obtain permission to use and share articles in this volume, visit Copyright Clearance Center at copyright.com. Other copying for republication, resale, advertising or promotion, or any form of systematic or multiple reproduction of any material in this book is prohibited except with permission in writing from the publisher.

Printed in the United States of America by Curran Associates, Inc., under license from SPIE.

Publication of record for individual papers is online in the SPIE Digital Library.

\section{SPIE. DIGITAL}

Paper Numbering: A unique citation identifier (CID) number is assigned to each article in the Proceedings of SPIE at the time of publication. Utilization of CIDs allows articles to be fully citable as soon as they are published online, and connects the same identifier to all online and print versions of the publication. SPIE uses a seven-digit CID article numbering system structured as follows:

- The first five digits correspond to the SPIE volume number.

- The last two digits indicate publication order within the volume using a Base 36 numbering system employing both numerals and letters. These two-number sets start with 00, 01, 02, 03, 04, 05, 06, 07, 08, 09, 0A, OB ... 0Z, followed by 10-1Z, 20-2Z, etc. The CID Number appears on each page of the manuscript. 


\section{Contents}

\section{HAZARD MITIGATION GEOLOGIC APPLICATIONS}

1186304 Post-earthquake response based on UAV, GNSS and TLS technologies: a recent example from Elassona earthquakes in Thessaly, Central Greece [11863-1]

1186305 In silico assessment of light penetration into snow: implications to the prediction of slab failures leading to avalanches [11863-2]

1186306 Rock-fall simulation and validation with in situ data: the case of Moira settlement in Western Greece [11863-3]

1186308 Identification of pegmatite bodies, at a province scale, using machine learning algorithms: preliminary results [1 1863-6]

1186309 Integration of geospatial information in a GIS software to estimate the forest fire risk [11863-7]

REMOTE SENSING FOR ARCHAEOLOGY, PRESERVATION OF CULTURAL AND NATURAL HERITAGE

$118630 \mathrm{~A} \quad$ Investigating the past using remote sensing techniques [1 1863-8]

$11863 \mathrm{OB} \quad$ Investigating the old city of Babylon: tracing buried structural history based on photogrammetry and integrated approaches [11863-9]

11863 OC A GIS open-source application to enhance the identification of archaeological crop marks using remote sensing data [11863-10]

11863 OD Using multitemporal remote sensing data for evaluation of the Kuibyshev reservoir bank transformation (Laishevo and Ostolopovo archaeological sites, Tatarstan, Russia) [11863-57]

\section{INFRASTRUCTURES AND URBAN AREAS}

11863 OG Monitoring water quantity in dam reservoir using Copernicus data [1 1863-14]

$11863 \mathrm{OH} \quad$ UAV-borne LiDAR and morphological filtering for automatic monitoring of alpine protective infrastructure [1 1863-15] 
SATELLITE RS AND GROUND-BASED NONDESTRUCTIVE TECHNOLOGIES IN CIVIL AND ENVIRONMENTAL ENGINEERING I

$118630 \mathrm{Ol} \quad$ Monitoring of bridges by MT-InSAR and unsupervised machine learning clustering techniques [11863-16]

$118630 \mathrm{~J}$ High resolution X-band SAR sensors: applications and trends for infrastructure monitoring in the framework of ASI's initiatives [11863-17]

11863 OK Synergistic monitoring of transport infrastructures by multi-temporal InSAR and GPR technologies: a case study in Salerno, Italy [11863-18]

$11863 \mathrm{OL} \quad$ A novel BIM approach for supporting technical decision-making process in transport infrastructure management [11863-19]

11863 OM Ground Penetrating Radar (GPR) and Mobile Laser Scanner (MLS) technologies for nondestructive analysis of transport infrastructures [1 1863-20]

11863 ON Evaluation of road pavement conditions by Deep Neural Networks (DNN): an experimental application [11863-21]

SATELLITE RS AND GROUND-BASED NONDESTRUCTIVE TECHNOLOGIES IN CIVIL AND ENVIRONMENTAL ENGINEERING II

1186300 Remote sensing and GIS paves the way for depth of cover pipeline analysis [11863-22]

$11863 \mathrm{OP} \quad$ Predicting international roughness index by deep neural networks with Levenberg-Marquardt backpropagation learning algorithm [1 1863-23]

$118630 Q \quad$ Tree trunk inspections using a polarimetric GPR system [11863-25]

11863 OR Advances in the use of the Short-Time Fourier Transform for assessing urban trees' root systems [11863-26]

11863 OS GPR image interpretation advancement for smarter technical management of water leakage in urban water infrastructures [1 1863-27]

\section{ENVIRONMENTAL MONITORING CONCEPTS}

11863 OT Comparison of two open-source tools for diachronic shoreline monitoring: a case study from northwestern Peloponnese [11863-28]

11863 OU Advanced remote sensing and GIS methods for restoration of the Lahontan cutthroat trout [1 1863-29]

$11863 \mathrm{OV} \quad$ Monitoring aquaculture fisheries using Sentinel-2 images by identifying plastic fishery rings [1 1863-30] 
$118630 \mathrm{X}$ Extrapolating forest canopy cover by combining airborne LiDAR and Landsat data: the case of the Yeste fire (Spain) [1 1863-32]

$118630 Z$ costeLAB: a cloud platform for monitoring activities and elements of coastal zones using satellite data [11863-34]

1186310 Land surface temperature algorithm calibration through meteorological stations [11863-35]

1186311 Assessment of the introduction of spatial stratification and manual training in automatic supervised image classification [1 1863-36]

1186312 Instance segmentation of deadwood objects in combined optical and elevation data using convolutional neural networks [11863-37]

1186313 Validation of low spatial resolution and no-dichotomy global long-term burned area product by Pareto boundary [1 1863-38]

1186314 Offshore oil slicks remote detection and discrimination from satellite data for monitoring [11863-39]

\section{POSTER SESSION}

1186315 Dynamics and development of Alepu marsh for the period 2013-2020 based on satellite data [11863-44]

1186317 Surface displacements determinations at "Fish-Fish" landslide area based on UAV photogrammetric surveys and remotely sensed SAR data [1 1863-47]

1186318 A satellite-based modified plant senescence reflectance index for green-water drought monitoring [11863-48]

$118631 \mathrm{~A} \quad$ Laboratory and field reflectance spectroscopy as a tool for sedimentary correlations in Paleoseismology [11863-50]

11863 1B Monitoring of surface water bodies by Sentinel and Open data [1 1863-51]

11863 1C Automated detection of illegal nonmetallic minerals mining places according to Sentinel-2 data [1 1863-52]

11863 1D Application of laboratory reflectance spectroscopy in the characterization of uranium-bearing minerals associated with fossils remains [11863-53] 
Proc. of SPIE Vol. $118631186301-6$

Downloaded From: https://www.spiedigitallibrary.org/conference-proceedings-of-spie on 26 Apr 2023
Terms of Use: https://www.spiedigitallibrary.org/terms-of-use 